\title{
PENINGKATAN KEMAMPUAN MENULIS RINGKASAN ISI CERITA MELALUI MODEL PEMBELAJARAN CIRC DI MIN 1 PESISIR SELATAN \\ Rendy $^{1}$, Nugraha Frasandy ${ }^{2}$, Surma Putri ${ }^{3}$ \\ Dosen PGMIUIN Imam Bonjol Padang, Guru MIN 1 Pesisir Selatan \\ Jl. Prof. Moh Yunus Lubuk Lintah, Kota Padang., rendy.nugraha04@yahoo.co.id \\ surmaputri22@gmail.com
}

\begin{abstract}
Indonesian language learning in the 2013 curriculum uses text or discourse. Text is used for writing and reading skills, while discourse is used for listening and speaking skills. One of the skills that is difficult for students to master is writing skills especially writing a summary of story content. The ability to write a summary of the story content of class V MIN 1 Pesisir Selatan has not yet reached the KKM. Students have not been able to determine the main ideas, spelling placement, use of punctuation and sort the main ideas of each paragraph. From the above problems, researchers applied a model that suits the characteristics of students, namely the Cooperative Integrated Reading and Composition (CIRC) learning model. This CIRC model is a comprehensive model in reading and writing in high class. The research method used is a classroom action research method with 2 cycles. Cycle I shows the results of the average score of 68.61 students with a completeness percentage of $44.44 \%$. In the second cycle shows the average score of students 81.94 with a percentage of $83.33 \%$ completeness.
\end{abstract}

Keywords: Writing Skills, Learning Model, CIRC

\begin{abstract}
Abstrak
Pembelajaran Bahasa Indonesia pada kurikulum 2013 menggunakan teks atau wacana. Teks digunakan untuk keterampilan menulis dan membaca, sedangkan wacana digunakan untuk keterampilan menyimak dan berbicara. Salah satu keterampilan yang sulit dikuasai peserta didik yaitu keterampilan menulis khususnya menulis ringkasan isi cerita. Kemampuan menulis ringkasan isi cerita kelas V MIN 1 Pesisir Selatan belum mencapai KKM. Peserta didik belum mampu menentukan gagasan utama, penempatan ejaan, penggunaan tanda baca dan mengurutkan gagasan pokok pikiran tiap paragraf. Dari permasalahan diatas, peneliti menerapkan model yang sesuai karakteristik peserta didik yaitu model pembelajaran Cooperative Integrated Reading and Composition (CIRC). Model CIRC ini merupakan model yang komprehensif dalam membaca dan menulis pada kelas tinggi. Metode penelitian yang digunakan yaitu metode penelitian tindakan kelas dengan 2 siklus. Siklus I menunjukkan hasil rata-rata nilai peserta didik 68,61 dengan persentase ketuntasan 44,44\%. Pada siklus II menunjukkan hasil rata-rata nilai peserta didik 81,94 dengan persentase ketuntasan $83,33 \%$.
\end{abstract}

Kata Kunci: Keterampilan Menulis, Model Pembelajaran, CIRC 


\section{PENDAHULUAN}

Bahasa Indonesia sebagai salah satu mata pelajaran yang berbasis kurikulum 2013 banyak menggunakan teks atau wacana. Teks digunakan dalam kaitannya dengan keterampilan menulis dan membaca. Wacana digunakan dalam kaitannya dengan keterampilan menyimak dan berbicara. Hal ini disebabkan pembelajaran Bahasa Indonesia sebagai salah satu mata pelajaran tematik integratif kurikulum 2013 di sekolah dasar tidak terlepas dari empat keterampilan berbahasa, yaitu menyimak, berbicara, membaca dan menulis. Salah satu keterampilan yang harus dikuasai peserta didik yaitu keterampilan menulis. Menulis sebagai keterampilan sesorang mengkomunikasikan pesan dalam sebuah tulisan.

Menurut Cahyani dan Hodijak dalam Ahmad Susanto (2013:242-243) pesan yang ditransaksikan itu berupa wujud ide (gagasan), kemampuan, perasaan atau informasi. Selanjutnya pesan tersebut dapat menjadi isi sebuah tulisan yang ditransaksikan kepada pembaca. Melalui sebuah tulisan, pembaca dapat memahami pesan yang ditransaksikan serta tujuan penulis. Senada dengan pendapat diatas menurut Badan Standar Nasional Pendidikan (BSNP), standar isi bahasa Indonesia sebagai berikut: "Pembelajaran bahasa Indonesia diarahkan untuk meningkatkan kemampuan peserta didik untuk berkomunikasi dalam bahasa Indonesia yang baik dan benar, baik secara lisan maupun tulisan, serta menumbuhkan apresiasi terhadap hasil karya kesastraan manusia Indonesia.

$$
\text { Menulis berkaitan dengan }
$$
membaca, bahkan dengan kegiatan berbicara dan menyimak. Membaca dan menulis merupakan kegiatan yang saling mendukung agar berkomunikasi untuk melakukan kegiatan membaca sebagai kegiatan dari latihan menulis. Menurut Tarigan dalam buku Ahmad Susanto (2013:247) menulis merupakan suatu kegiatan yang produktif dan ekspresif. Dalam kegiatan menulis, penulis harus terampil memanfaatkan struktur bahasa dan kosa kata.

Menurut Romania Magdalena (2017:194) dengan judul penelitian "Peningkatan Keterampilan Menulis Ringkasan Teks Bacaan melalui Pembelajaran Tipe Cooperative Integrated Reading And Composition" menunjukkan bahwa terjadinya peningkatan hasil belajar peserta didik dalam menulis ringkasan teks bacaan. Hal ini dapat dilihat dari siklus I persentase hasil belajar 74,58\% dan pada siklus II meningkat menjadi $86 \%$. Lebih lanjut Ikhsan Akbari (2013:30) dengan judul penelitian "Penerapan Model Pembelajaran Kooperatif Tipe Cooperative Integrated Reading And Composition (CIRC) untuk Meningkatkan Kemampuan Meringkas Isi Buku Cerita Siswa Kelas V SDN 02 Ngasem Colomadu Karanganyar" menunjukkan bahwa terjadinya peningkatan kemampuan meringkas isi 
buku cerita. Hal ini dapat dilihat dari siklus I meningkat menjadi $72 \%$, kemudian pada siklus II persentase ketuntasan meningkat lagi menjadi $88 \%$.

Susanti (2014:60) penelitian yang dilakukan oleh Susanti dengan judul "Peningkatan Kemampuan Menulis Ringkasan Isi Cerita Melalui Model Pembelajaran Kooperatif Tipe Cooperative Integrated Reading And Composition (CIRC) Pada Peserta Didik Kelas V SDN 04 Olo Kecamatan Nanggalo". Dari hasil penelitian Susanti menunjukkan bahwa terjadinya peningkatan hasil belajar peserta didik dalam menulis ringkasan isi cerita. Hal ini dapat dilihat dari siklus I persentase hasil belajar $68,75 \%$ dan pada siklus II meningkat menjadi $80,89 \%$.

Perbedaan penelitian ini dengan penelitian-penelitian sebelumnya, pada penelitiann sebelumnya hasil penelitian didapat hanya dengan membandingkan hasil belajar pada siklus 1 dan siklus 2 . Sedangkan pada penelitian ini peningkatan kemampuan menulis isi cerita peserta didik tergambar melalui alur PTK yaitu melihat dari perencanaan, pelaksanaan, hasil belajar tiap siklus, observasi dan pengamatan dan refleksi diakhir kegiatan. Sehingga data dapat dibaca secara lebih detail dan komprehensif.

Menurut Suyatno dalam Istarani Ridwan Muhammad (2014:101) pembelajaran Cooperative Integrated Reading And Composition adalah komposisi terpadunya membaca dan menulis secara kooperatif kelompok.
Sintaknya adalah: membentuk kelompok heterogen 4 orang, guru memberikan bahan bacaan sesuai materi, siswa bekerja sama (membaca bergantian, menemukan kata kunci, memberikan tanggapan), menuliskan hasil kolaboratif, presentasi kelompok, dan refleksi. Penggunaan model kooperatif tipe CIRC sangat membantu peserta didik pada pembelajaran menulis ringkasan. Karena model kooperatif tipe CIRC bersifat kooperatif sehingga dapat meningkatkan kerjasama antar peserta didik, semua peserta didik dibimbing dan diarahkan untuk aktif dan kreatif sehingga waktu pembelajaran menjadi lebih efektif dan efisien. Model pembelajaran kooperatif tipe CIRC ini mengintegrasikan antara pembelajaran membaca dan menulis secara bersamaan, sehingga tepat dengan karakteristik pembelajaran bahasa Indonesia yaitu terpadu.

Menurut Faisal (2014:24-25) karakteristik peserta didik SD adalah senang bekerja dalam kelompok. Dari pergaulannya dalam kelompok sebaya, peserta didik belajar aspek-aspek yang penting dalam proses sosialisasi, seperti: belajar memenuhi aturan-aturan kelompok, belajar setia kawan, belajar tidak tergantung pada diterimanya di lingkungan, belajar menerima tanggung jawab, belajar bersaing dengan orang lain secara sehat (sportif), dan mempelajari olahraga. Hal ini membawa implikasi bahwa pendidik harus merancang metode pembelajaran yang memungkinkan peserta didik untuk bekerja atau belajar dalam 
kelompok, belajar keadilan serta demokrasi. Pendidik dapat meminta peserta didik untuk membentuk kelompok kecil dengan anggota 3-4 orang untuk mempelajari atau menyelesaikan suatu tugas secara kelompok.

Rendahnya kemampuan menulis ini terlihat ketika pendidik memberikan latihan menulis ringkasan pada tanggal 24 Oktober 2017 "tema 2 peristiwa dalam kehidupan sub tema 2 peristiwa peristiwa penting pembelajaran 4 materi berkunjung ke museum perjuangan". Peserta didik belum mampu menentukan gagasan utama tiap paragraf pada sebuah cerita, penempatan ejaan yang belum benar dan penggunaan tanda baca yang belum tepat serta belum mampu mengurutkan gagasan pokok pikiran tiap paragraf. Hal itu terbukti ketika peserta didik diminta untuk meringkas namun faktanya peserta didik menulis isi cerita persis sama dengan cerita aslinya.

Proses pembelajaran yang didominasi oleh pendidik dengan metode yang konvensional dan menutup peluang untuk peserta didik berperan aktif saat pembelajaran menulis ringkasan isi cerita. Sehingga pembelajaran menjadi tidak menarik serta suasana belajar tidak menyenangkan. Dalam kondisi dan situasi seperti itu kemampuan peserta didik untuk menerima materi pembelajaran pun tidak maksimal. Hal tersebut tercermin dari nilai tes yang belum memuaskan. Oleh karena itu kemampuan menulis ringkasan perlu ditingkatkan dengan menerapkan model pembelajaran yang baru dan berbeda dari pembelajaran sebelumnya, agar kemampuan menulis ringkasan isi cerita peserta didik dapat meningkat. Untuk itu tujuan penelitian ini adalah untuk mengetahui peningkatan kemampuan menulis ringkasan isi cerita peserta didik melalui model pembelajaran CIRC di MIN 1 Pesisir Selatan.

\section{METODE PENELITIAN}

Penelitian yang akan digunakan adalah Penelitian Tindakan Kelas (PTK). Menurut Zainal Aqib (2009:19) Penelitian tindakan kelas (Classroom Action Research) yaitu penelitian yang dilakukan oleh guru di kelas atau di sekolah tempat ia mengajar dengan penekanan pada penyempurnaan atau peningkatan proses dan praktek pembelajaran. Menurut Harjodipuro dalam Dadang Yudhistira (2013:28) PTK adalah suatu pendekatan untuk memperbaiki pendidikan melalui perubahan, dengan mendorong para guru untuk memikirkan praktik mengajarnya sendiri, agar kritis terhadap praktik tersebut dan agar mau untuk mengubahnya.

Penelitian tindakan kelas disini merupakan penelitian yang bersifat kolaborasi, dalam penelitian kolaborasi pihak yang melakukan tindakan adalah pendidik itu sendiri, sedangkan yang melakukan pengamatan terhadap berlangsungnya proses tindakan adalah peneliti, bukan pendidik yang melakukan tindakan. Penelitian yang penulis lakukan bertujuan untuk 
meningkatkan kemampuan menulis ringkasan di kelas $\mathrm{V}$ dengan menerapkan model Pembelajaran kooperatif tipe Cooperative Integrated Reading And Composition. Penelitian difokuskan pada perencanaan, pelaksanaan, dan penilaian proses pembelajaran dengan menggunakan pendekatan kualitatif. Pendekatan kualitatif digunakan karena kualitatif merupakan suatu prosedur penelitian yang menghasilkan data deskriptif berupa kata-kata tertulis atau lisan, serta prilaku yang dapat diamati dari orangorang atau sumber informasi. Berdasarkan masalah dan tujuan penelitian yang telah dikemukakan, maka jenis penelitian ini adalah Penelitian Tindakan Kelas dengan menggunakan metode penelitian tindakan kelas. Model PTK yang digunakan dalam penelitian ini adalah Model spiral dari Kemmis \& Mc Taggart.

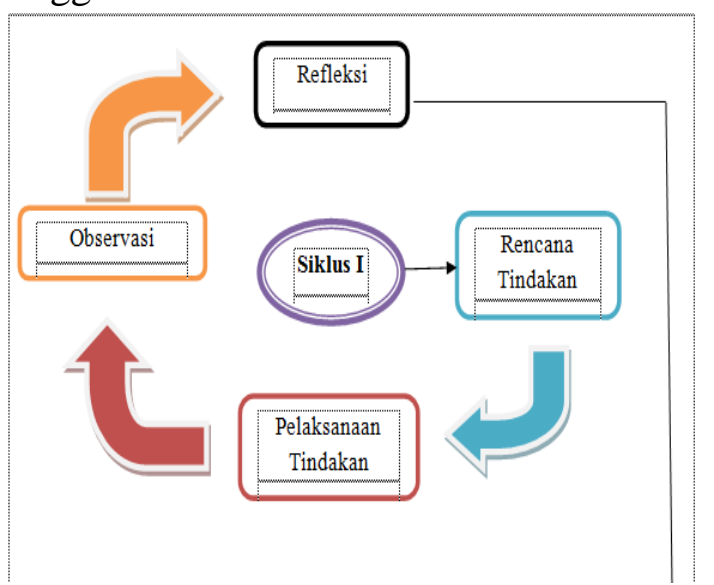

Gambar 1 Alur Penelitian Tindakan Kelas

Model yang dikembangkan oleh Kemmis \& Mc Taggart dilakukan melalui empat tahapan mulai perencanaan, pelaksanaan, observasi, dan refleksi. Alur siklus saling berkelanjutan dan berkesinambungan. Siklus pertama berdasarkan masalah yang teramati, jika hasilnya masih kurang maka dilanjutkan ke siklus berikutnya yang merupakan perbaikan dari siklus pertama. Siklus dihentikan jika hasil penelitian sudah dirasa cukup dan memenuhi tujuan yang diharapkan.

\section{Sumber Data}

Sehubungan dengan jenis data yang diperlukan maka sumber data yang diperlukan adalah:

1. Seluruh peserta didik kelas V MIN 1 Pesisir Selatan menjadi kelas sampel untuk mendapatkan data primer.

2. Kepala sekolah, pegawai tata usaha dan pendidik kelas V MIN 1 Pesisir Selatan.

\section{Teknik dan Instrumen Pengumpulan Data}

a. Observasi

Data penelitian ini dikumpulkan dengan menggunakan teknik observasi. Pada dasarnya berupa pengamatan terhadap tindakan praktisi sewaktu pembelajaran Bahasa Indonesia dengan model pembelajaran kooperatif tipe Cooperative Integrated Reading And Composition. Observasi kemampuan menulis ringkasan peserta didik dilakukan saat pembelajaran berlangsung dengan menggunakan lembar observasi menulis ringkasan 
peserta didik. Nilai ringkasan yang dicari yaitu nilai menemukan gagasan utama dan penggunaan tanda baca yang tepat per individu dan ketuntasan secara klasikal.

b. Tes akhir tindakan

Tes berupa butir-butir soal diberikan kepada peserta didik dalam bentuk evaluasi. Evaluasi ini diberikan dalam bentuk teks cerita sesuai materi, pemberian teks ini bertujuan untuk mengukur atau mengetahui kemampuan peserta didik dalam memahami materi pembelajaran. Soal tes/pemberian teks evaluasi diberikan kepada masing-masing peserta didik di setiap kali pertemuan. Kegiatan tes yang digunakan adalah berupa teks cerita terkait materi yang diajarkan.

\section{c. Dokumentasi}

Teknik dokumentasi ini digunakan untuk memperoleh data visual mengenali aktivitas guru, aktivitas belajar peserta didik, serta untuk melengkapi data yang terlibat pada situasi dan kondisi yang terjadi dilapangan pada saat melaksanakan proses pembelajaran Bahasa Indonesia dengan menggunakan model pembelajaran koopeatif tipe Cooperative Integrated Reading And Composition di kelas V MIN 1 Pesisir Selatan berupa foto-foto yang tejadi apabila terlepas dari pengamatan peneliti saat observasi. Kamera digunakan untuk memperoleh foto-foto atau dokumentasi.

\section{Prosedur Penelitian}

Penilitian ini mengacu pada desain PTK yang telah dirumuskan, antara lain ada 4 komponen yaitu: perencanaan, pelaksanaan, pengamatan, dan refleksi. Tahap-tahap pelaksanaannya adalah:

\section{Perencanaan (Planning)}

Sesuai dengan rumusan masalah hasil studi pendahuluan, peneliti membuat rencana tindakan yang akan dilakukan, tindakan itu berupa proses pembelajaran melalui model pembelajaran kooperatif tipe Cooperative Integrated Reading And Composition untuk meningkatkan kemampuan menulis ringkasan peserta didik kelas V MIN 1 Pesisir Selatan.

Kegiatan ini dimulai dengan merumuskan rancangan tindakan proses pembelajaran, dengan model pembelajaran Cooperative Integrated Reading And Composition. Kegiatan tersebut adalah sebagai berikut:

a. Menyusun rancangan berupa RPP.

Dalam penyusunan RPP, pendidik harus mengacu pada standar isi yang mana RPP memuat standar kompetensi dasar, indikator, tujuan pembelajaran, materi pokok, langkah-langkah pembelajaran, alat/ sumber dan penelitian.

b. Peneliti membuat perencanaan, melaksanakan, dan menilai proses 
pembelajaran model pembelajaran kooperatif tipe Cooperative Integrated Reading and Composition untuk meningkatkan kemampuan menulis ringkasan peserta didik kelas V MIN 1 Pesisir Selatan.

c. Menetapkan waktu mulai melakukan penelitian tindakan.

d. Memilih dan menentukan buku sumber yang sesuai dengan materi.

e. Menyiapkan instrumen penelitian: lembar observasi menulis ringkasan peserta didik.

\section{Pelaksanaan Tindakan (Acting)}

Tahap ini dimulai pelaksanaan pembelajaran Bahasa Indonesia. Sesuai dengan perencanaan peneliti dilakukan 2 siklus kegiatan dengan masing-masing tahapan berikut ini:

Tabel $1 \quad$ Skenario Pembelajaran Menulis Ringkasan Isi Cerita Menggunakan Model Pembelajaran Cooperative Integrated Reading and Composition

\begin{tabular}{|c|c|}
\hline Kegiatan & Deskripsi Kegiatan \\
\hline Pendahuluan & $\begin{array}{l}\text { 1. Pendidik } \\
\text { mengucapkan salam } \\
\text { 2. Pendidik menyapa } \\
\text { peserta didik dan } \\
\text { menanyakan kabar } \\
\text { peserta didik. } \\
\text { 3. Pendidik } \\
\text { mengkondisikan kelas } \\
\text { dan peserta didik } \\
\text { untuk memulai } \\
\text { pelajaran. } \\
\text { 4. Pendidik meminta } \\
\text { salah seorang peserta } \\
\text { didik memimpin doa. } \\
\text { 5. Pendidik mengecek } \\
\text { kehadiran peserta }\end{array}$ \\
\hline
\end{tabular}

\begin{tabular}{|c|c|}
\hline & $\begin{array}{l}\text { didik. } \\
\text { 6. Pendidik melakukan } \\
\text { apersepsi } \\
\text { Kemudian Pendidik } \\
\text { mengaitkan pertanyaan } \\
\text { tersebut dengan materi } \\
\text { yang akan dipelajari. } \\
\text { 7. Pendidik memberi } \\
\text { motivasi dan } \\
\text { menyampaikan tujuan } \\
\text { pembelajaran. }\end{array}$ \\
\hline Inti & 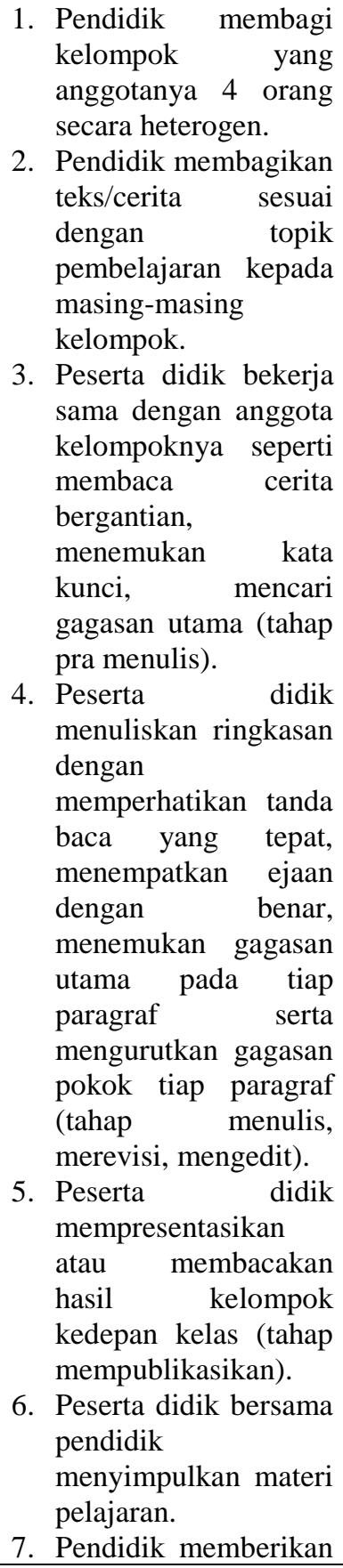 \\
\hline
\end{tabular}




\begin{tabular}{|c|c|}
\hline & reward/hadiah \\
\hline Penutup & $\begin{array}{l}\text { 1. Pendidik bertanya } \\
\text { kepada peserta didik } \\
\text { tentang materi yang } \\
\text { belum di pahami. } \\
\text { 2. Pendidik } \\
\text { membimbing } \\
\text { peserta didik untuk } \\
\text { menyimpulkan } \\
\text { materi yang telah } \\
\text { dipelajari. } \\
\text { 3. Pendidik } \\
\text { memberikan PR } \\
\text { kepada peserta } \\
\text { didik, sebagai tindak } \\
\text { lanjut. } \\
\text { 4. Pendidik mengakhiri } \\
\text { proses pembelajaran } \\
\text { dengan berdoa. } \\
\text { 5. Pendidik } \\
\text { mengucapkan salam } \\
\text { sebelum pulang. }\end{array}$ \\
\hline
\end{tabular}

3. Observasi (Observing)

Dalam kegiatan ini peneliti dan observer dalam usaha mengecek dan mengkomunikasikan dari proses yang terjadi, keseluruhan hasil pengamatan dalam lembar observasi. Pengamatan pada siklus pertama akan berpengaruh pada siklus berikutnya. Kegiatan observasi ini peneliti melakukan untuk mengambil proses belajar peserta didik selama pembelajaran dengan menggunakan model pembelajaran kooperatif tipe Cooperative Integrated reading And Composition. Pelaksanaan kegiatan ini bersamaan dengan pelaksanaan tindakan pembelajaran.

\section{Refleksi (Reflecting)}

Refleksi yang dimaksud dalam penelitian ini yaitu melakukan perbaikan yang ditemukan dalam kegiatan observasi untuk dicarikan solusi sehingga pembelajaran lebih efektif dan sesuai dengan harapan seperti, melakukan pemeriksaan terhadap hasil evaluasi belajar peserta didik dan mengganti soalsoal yang dianggap sulit oleh peserta didik, mengganti media pembelajaran dalam bentuk variasi lebih bagus lagi agar pembelajaran berjalan lebih baik serta tidak monoton dan meningkatkan kemampuan peserta didik.

Setelah selesai suatu tindakan peneliti melakukan refleksi diri dalam tahap ini peneliti menganalisis tindakan yang sudah peneliti lakukan dalam proses pembelajaran, menelaah kembali rancangan RPP dan pelaksanaan tindakan yang peneliti lakukan, dan mengambil kesimpulan dari apa yang sudah peneliti lakukan. Hasil dapat dimanfaatkan sebagai masukan pada tindakan, selanjutnya hasil refleksi menyusun kesimpulan terhadap hasil tindakan dan dijadikan landasan untuk memperbaiki.

\section{Teknik Analisis Data}

Menurut Anas Sudijono (2014:43) data yang diperoleh dalam penelitian ini akan dianalisis dengan menggunakan analisis kualitatif yang dijelaskan sebagai berikut:

1. Analisis Data Kualitatif

Data kualitatif diperoleh melalui kegiatan pengamatan (observasi). Pada penelitian ini, yang termasuk dalam data kualitatif adalah kemampuan menulis ringkasan 
peserta didik selama pembelajaran berlangsung. Data yang diperoleh dianalisis menggunakan analisis data kualitatif berikut. Data kemampuan menulis ringkasan peserta didik diperoleh dari hasil pengamatan ketika pembelajaran berlangsung.

Nilai aktivitas belajar peserta didik diperoleh dengan rumus:

$$
P=\frac{f}{N} x 100 \%
$$

Keterangan :

$\mathrm{P}=$ Persentase kemampuan menulis ringkasan peserta didik

$\mathrm{f}=$ Skor yang diperoleh peserta didik

$$
\begin{aligned}
& \mathrm{N}=\text { Jumlah Skor maksimum } \\
& 100 \%=\text { Bilangan tetap }
\end{aligned}
$$

Hasil analisis ini dilakukan untuk melakukan perencanaan pada siklus selanjutnya sebagai bahan refleksi dalam memperbaiki rancangan pembelajaran Cooperative Integrated Reading And Composition.

\section{HASIL DAN PEMBAHASAN \\ Hasil Siklus I \\ a. Pertemuan Pertama Siklus 1 \\ 1) Perencanaan}

Tahap perencanaan dimulai dengan mempersiapkan RPP (Rencana

Pembelajaran) Pelaksanaan menggunakan dengan pembelajaran model Integrated Reading and Composition, menetapkan tujuan pembelajaran, menentukan media pembelajaran,

membuat lembar pengamatan aspek peserta didik dan pendidik, membuat soal evaluasi dan kunci jawaban untuk siklus I. instrumen pengumpulan data yang digunakan adalah lembar pengamatan untuk setiap kali pertemuan dan seperangkat tes hasil belajar.

Penyusunan rancangan pembelajaran ini disusun secara kolaboratif antara peneliti dengan pendidik kelas V MIN 1 Pesisir Selatan. RPP disusun sesuai Kurikulum 2013, namun di MIN 1 Pesisir Selatan pendidik belum menerapkan pembelajaran tematik terpadu, sehingga pembelajaran dilaksanakan secara terpisah sesuai dengan muatan KD setiap mata pelajaran. Sebagai pedoman bagi pendidik dalam pelaksanaan pembelajaran yang mencakup muatan KD bahasa Indonesia semester II meringkas teks penjelasan dari media cetak atau elektronik serta menyajikan ringkasan teks penjelasan dari media cetak dan elektronik.

Adapun mencapai tujuan pembelajaran bahasa Indonesia di kelas $\mathrm{V}$ maka dalam pembelajaran menulis ringkasan, pendidik melakukan tahap pembelajaran menulis yang terdiri dari; 1) kegiatan awal, 2) kegiatan inti yang terbagi atas pramenulis, menulis (merevisi dan mengedit) 
dan pascamenulis (mempublikasikan) 3) kegiatan akhir. Kegiatan ini saling terkait satu sama lainnya. Kegiatan belajar mengajar yang direncanakan dalam pembelajaran ini terdiri atas kegiatan pendidik dan peserta didik. Adapun kegiatan pendidik di mulai dari kegiatan awal yaitu menyiapkan kondisi kelas, menyiapkan alat pembelajaran, berdoa, mencek kehadiran peserta didik, apersepsi tentang menulis ringkasan isi cerita. Kemudian dilanjutkan dengan kegiatan inti yaitu tahap pramenulis, tahap menulis (mengedit, merevisi) dan tahap pascamenulis (mempublikasikan).

Pertemuan pertama siklus 1 direncanakan pada tahap pramenulis dimulai dengan memberikan sebuah pemodelan menulis ringkasan dengan menggunakan model pembelajaran Cooperative Integrated Reading and Composition. Adapun pada kegiatan pramenulis ini kegiatan pendidik dan peserta didik yaitu: a) Pendidik membagi kelompok secara heterogen, b) Pendidik menempelkan media kemudian meminta peserta didik untuk menjelaskan gambar tersebut masing-masing kelompok, c) Pendidik menjelaskan langkahlangkah menulis ringkasan, d) Pendidik menyebutkan kembali langkah-langkah menulis ringkasan, e) Pendidik memberikan teks kepada setiap peserta didik.

Pertemuan pertama siklus 1 ini pendidik menjelaskan tentang langkah-langkah menulis ringkasan, penggunaan ejaan dan tanda baca serta menemukan gagasan utama dengan menerapkan model pembelajaran Cooperative Integrated Reading and Composition.

\section{2) Pelaksanaan}

\section{a) Kegiatan Pendahuluan}

Pada

kegiatan pendahuluan ini berlangsung kurang lebih selama 10 menit. Pada tahap ini pendidik mempersiapkan peserta didik untuk mengikuti kegiatan pembelajaran, meriview pelajaran yang lalu dengan mengajukan pertanyaan dan mengaitkan pengetahuan sebelumnya dengan materi yang akan dipelajari, memberikan motivasi dengan mengajukan pertanyaan, "siapa yang pernah meringkas buku pelajaran?" tanya pendidik. Peserta didik menjawab "pernah bu". Kemudian pendidik menyampaikan tujuan pembelajaran.

\section{b) Kegiatan inti}

Menulis ringkasan mempunyai beberapa tahapan diantaranya tahap pramenulis, menulis dan pascamenulis. Pada pertemuan pertama siklus 
I pendidik menjelaskan tahap pramenulis. Tahap ini diawali dengan menulis ringkasan oleh peserta didik dengan menggunakan model pembelajaran Cooperative Integrated Reading and Composition dengan langkahlangkah yaitu: pembentukan kelompok secara heterogen, menempel media pembelajaran, menjelaskan langkah-langkah menulis ringkasan, pemberian teks pada setiap peserta didik.

\section{c) Kegiatan penutup}

Pada kegiatan ini, peserta didik dibimbing untuk menyimpulkan pembelajaran tentang menulis ringkasan. Selanjutnya diberikan penjelasan bahwa pelajaran ini akan dilanjutkan pada minggu depan. Kemudian pelajaran ditutup dengan membaca hamdalah bersama peserta didik dan mengucapkan salam

\section{b. Pertemuan Kedua Siklus I}

\section{1) Perencanaan}

Berdasarkan hasil penelitian pada pertemuan I dan setelah didiskusikan refleksi terhadap materi ajar pada pertemuan I belum menunjukkan ketuntasan. Sehingga pembelajaran dilanjutkan pada pertemuan II. Pada kegiatan ini peneliti berkolaborasi dengan pendidik kelas V MIN 1 Pesisir Selatan. Sebelum pembelajaran berlangsung terlebih dahulu dipersiapkan RPP, memilih media yang sesuai dengan materi pelajaran, membuat pertanyaan tentang materi ajar. Pada pertemuan kedua siklus 1 ini pendidik menerapkan langkahlangkah menulis ringkasan dan model pembelajaran Cooperative Integrated Reading and Composition dengan memberikan teks cerita tentang pengaruh negatif interaksi manusia dengan lingkungan alamnya.

\section{2) Pelaksanaan}

a) Kegiatan Pendahuluan

$$
\text { Pada }
$$

kegiatan pendahuluan ini berlangsung kurang lebih selama 10 menit. Pada tahap ini pendidik mempersiapkan peserta didik untuk mengikuti kegiatan pembelajaran, meriview pelajaran yang lalu dengan mengajukan pertanyaan dan mengaitkan pengetahuan sebelumnya dengan materi yang akan dipelajari, memberikan motivasi dengan mengajukan pertanyaan "anakanak Ibu, apakah anak-anak ibu tau apa yang akan terjadi jika kita membuang sampah sembarangan?". Peserta didik menjawab pertanyaan pendidik. Kemudian pendidik menyampaikan tujuan pembelajaran.

b) Kegiatan inti 
Pada pertemuan kedua ini, pendidik meminta peserta didik untuk duduk berkelompok sesuai dengan kelompok yang telah ditentukan pada pertemuan sebelumnya. Setelah peserta didik duduk dalam kelompok masing-masing, pendidik membagikan teks cerita kepada setiap kelompok dan melaksanakan pembelajaran dengan menerapkan langkahlangkah model pembelajaran Cooperative Integrated Reading and Composition.

Pada saat bekerja dalam kelompok diskusi, pendidik meminta peserta didik untuk membacakan teks secara bergantian seperti ketika peserta didik membaca peserta didik yang lainnya menyimak. Setelah selesai membaca peserta didik menemukan kata kunci, menemukan gagasan utama setiap paragraf dan membuat ringkasan dari teks tersebut dengan memperhatikan tanda baca dan ejaan yang benar. Kemudian tahap merevisi dan mengedit yaitu: a) setiap kelompok memperbaiki tulisan yang telah ditulisnya, b) peserta didik menyalin ringkasan yang telah diperbaiki.

Tahap pasca menulis yaitu kegiatan mempublikasikan. Masing- masing perwakilan kelompok membacakan ringkasan ke depan kelas dengan intonasi yang tepat dan peserta didik lainnya memperhatikan.

c) Kegiatan penutup

Pada kegiatan ini, peserta didik dibimbing untuk menyimpulkan pembelajaran ringkasan tentang pengaruh negatif interaksi manusia dengan lingkungan alamnya. Selanjutnya diberikan penjelasan bahwa pelajaran ini akan dilanjutkan pada minggu depan. Kemudian pelajaran ditutup dengan membaca hamdalah bersama peserta didik dan mengucapkan salam. Pada pertemuan selanjutnya pendidik memberikan tes siklus I untuk mengetahui kemampuan menulis ringkasan isi cerita.

\section{c. Observasi/Pengamatan}

Pengamatan dilakukan secara terus menerus mulai dari tindakan pertama sampai tindakan berakhir. Pengamatan yang dilakukan pada satu tindakan dapat mempengaruhi penyusunan tindakan selanjutnya. Hasil pengamatan ini kemudian direfleksikan untuk perencanaan tindakan selanjutnya.

\section{d. Hasil Belajar Siklus I}

Penilaian peserta didik meliputi penilaian proses pada saat pramenulis, menulis, merevisi, mengedit dan mempublikasikan. Penilaian menulis ringkasan 
menggunakan model pembelajaran Cooperative Integrated Reading and Composition dengan KKM yang telah ditetapkan sekolah yaitu 75 . Pendidik memberikan tes diskusi kelompok setiap pertemuan. Pertemuan I terdapat satu kelompok yang di atas KKM yaitu kelompok tiga dengan nilai 75 . Karena masih banyak peserta didik yang belum paham dalam menulis ringkasan. Hal itu terbukti dari 4 kelompok yang tuntas hanya terdapat satu kelompok. Peserta didik belum serius dalam belajar. Pertemuan II terdapat dua kelompok yaitu kelompok dua dan tiga dengan nilai 75 dan 75 . Peserta didik belum mengerti menemukan gagasan utama karena pendidik menggunakan bahasa buku. Pertemuan III yaitu kelompok tiga dan empat dengan nilai 85 dan 85 . Peserta didik kesulitan dalam menemukan gagasan utama, menempatkan tanda baca serta penggunaan ejaan. Sedangkan pada pertemuan IV pendidik melakukan tes siklus I dari 18 orang peserta didik terdapat 8 orang peserta didik yang tuntas sedangkan 10 orang peserta didik belum tuntas. Hal ini didominasi karena peserta didik masih kesulitan dalam menemukan gagasan utama setiap paragraf, mengurutkan gagasan utama menjadi sebuah ringkasan.

\section{e. Refleksi}

Kegiatan refleksi dilakukan pada setiap tahapan pembelajaran dilakukan secara kolaboratif antara wali kelas V MIN 1 Pesisir Selatan dengan peneliti. Pembelajaran siklus I mencakup tahap model pembelajaran Cooperative Integrated Reading and Composition melalui tahapan pramenulis, menulis, merevisi, mengedit, dan tahap pascamenulis yaitu mempublikasikan.

1) Refleksi tahap pramenulis dan menulis pada pertemuan pertama dan kedua

Pada awal tahap ini pendidik menyiapkan kondisi kelas. Kemudian pendidik menjelaskan tujuan pembelajaran yang akan dipelajari sudah berjalan baik. Pada kegiatan menjelaskan pengertian menulis ringkasan, gagasan utama, langkah-langkah dalam menulis ringkasan serta penggunaan tanda baca dalam teks tidak berjalan lancar karena peserta didik kurang memahami tentang menulis ringkasan serta langkah-langkahnya, menentukan gagasan utama serta penggunaan tanda baca yang tepat. Sehingga pada saat pendidik bertanya sebagian besar peserta didik hanya diam. Selanjutnya ketika pendidik membagi peserta didik ke dalam beberapa kelompok sudah berjalan baik tetapi masih ada peserta didik yang memilih teman dalam berkelompok. Peserta didik cenderung lebih memilih teman dekat mereka. Sehingga pendidik membagi peserta didik secara heterogen 
yang terdiri dari 4 kelompok yang beranggotakan 4-5 orang. Peserta didik duduk dikelompok yang telah ditetapkan pendidik.

$$
\text { Pada saat pendidik }
$$

menjelaskan langkah-langkah menulis ringkasan pendidik masih menggunakan bahasa buku sehingga peserta didik sulit memahami penjelasan pendidik. Untuk hal ini pendidik perlu menggunakan bahasa yang mudah dimengerti peserta didik.

Pada saat bekerja dalam kelompok masih ada peserta didik yang tidak ikut berdiskusi dan kurang serius dalam belajar seperti pada saat membaca bergantian masih ada peserta didik yang tidak menyimak. Pada saat menulis peserta didik terlihat kebingungan dalam menentukan gagasan utama. Untuk hal ini pendidik dan peneliti lebih mengawasi dan mengontrol peserta didik sehingga saat bekerja dalam kelompok semua peserta didik ikut berdiskusi.

Pada tahap ini peserta didik masih ada yang belum tepat dalam penempatan tanda baca serta mengalami kesulitan dalam menentukan gagasan utama setiap paragraf. Sehingga pendidik meminta peserta didik untuk membaca ulang lalu mengoreksi hasil diskusinya. Pada saat membacakan hasil diskusi peserta didik ada yang meribut, sehingga peserta didik yang tampil suaranya kurang jelas. Sehingga pendidik memberikan arahan kepada peserta didik untuk memperhatikan temannya yang tampil. Pendidik juga meminta peserta didik untuk mengomentari penampilan temannya. Pendidik memberikan apresiasi kepada peserta didik yang aktif dan bersungguh-sungguh dalam belajar.

\section{Hasil Siklus II}

a. Pertemuan pertama Siklus II

\section{1) Perencanaan}

Penggunaan

model

pembelajaran Cooperative Integrated Reading and Composition dalam menulis ringkasan disusun dan diwujudkan dalam bentuk rencana pelaksanaan pembelajaran. Perencanaan yang dibuat pada siklus II pada garis besarnya sama dengan siklus I. Perbedaannya yaitu pada siklus II terdapat pada teks yang akan didiskusikan peserta didik. Pada saat menjelaskan menulis ringkasan pendidik menggunakan bahasa yang mudah dimengerti peserta didik, memberikan contoh yang sederhana yang sehingga peserta didik mudah memahaminya. Pendidik lebih memantau, mengawasi serta mengontrol keseriusan peserta didik dalam menulis ringkasan dengan cara pendidik memberikan beberapa pertanyaan kepada masing-masing kelompok terkait menulis ringkasan. 
Kegiatan merevisi dan mengedit pendidik berupaya memancing keseriusan peserta didik untuk merevisi dan mengedit tulisan yang telah diselesaikan dengan cara lebih mengontrol peserta didik mengerjakan tugasnya.

Kegiatan mempublikasikan pendidik meminta peserta didik membacakan hasil diskusi ke depan kelas dengan suara yang lantang dan intonasi yang tepat. Memberikan komentar pada kelompok yang tampil serta pendidik memberikan apresiasi berupa skor tertinggi kepada kelompok yang serius dalam belajar sehingga peserta didik termotivasi dalam belajarnya.

\section{2) Pelaksanaan}

a) Kegiatan Pendahuluan

Pada kegiatan pendahuluan ini berlangsung kurang lebih selama 10 menit. Pada tahap ini pendidik mempersiapkan peserta didik untuk mengikuti kegiatan pembelajaran, meriview pelajaran yang lalu dengan mengajukan pertanyaan dan mengaitkan pengetahuan sebelumnya dengan materi yang akan dipelajari, kemudian menyampaikan tujuan pembelajaran.

b) Kegiatan inti

Pelaksanaan pembelajaran Cooperative Integrated Reading and Composition dalam menulis ringkasan melalui beberapa tahap yaitu pramenulis, menulis, merevisi, mengedit dan pascamenulis yaitu mempublikasikan.

Tahap pramenulis diawali dengan menulis ringkasan oleh peserta didik dengan menggunakan model pembelajaran Cooperative Integrated Reading and Composition dengan langkahlangkah yaitu pembentukan kelompok secara heterogen, menempel media pembelajaran, menjelaskan langkah-langkah menulis ringkasan, pemberian teks pada setiap peserta didik. Pendidik menjelaskan dengan bahasa yang mudah dimengerti tentang menulis ringkasan, penggunaan tanda baca dan ejaan serta menemukan gagasan utama. Sehingga peserta didik mengerti tentang menulis ringkasan.

Tahap menulis peserta didik bekerja sama dalam kelompoknya. Peserta didik saling berdiskusi untuk membuat ringkasan. Peserta didik menulis ringkasan dengan memperhatikan tanda baca, ejaan yang tepat, menemukan gagasan utama setiap paragraf serta mengurutkan gagasan pokok tiap paragraf.

c) Kegiatan penutup

Pada kegiatan ini, peserta didik dibimbing untuk menyimpulkan pembelajaran, berdoa dan salam. 


\section{b. Pertemuan kedua Siklus II}

Hasil analisis hasil refleksi siklus II pertemuan I menunjukkan subjek penelitian belum mencapai tujuan yang diharapkan. Oleh karena itu pembelajaran dilanjutkan dengan siklus II pertemuan II.

\section{1) Perencanaan}

Pada kegiatan ini peneliti berkolaborasi dengan pendidik kelas V MIN 1 Pesisir Selatan. Sebelum pembelajaran berlangsung terlebih dahulu dipersiapkan RPP, memilih media yang sesuai dengan materi pelajaran, lembar pengamatan proses pembelajaran untuk aspek peserta didik dan pendidik, serta tes diskusi kelompok. Pada tahap ini pendidik menyampaikan materi menggunakan bahasa yang mudah dimengerti peserta didik, pendidik lebih mengontrol dan mengawasi peserta didik dalam pembelajaran.

\section{2) Pelaksanaan}

a) Kegiatan Pendahuluan

Pada kegiatan pendahuluan ini berlangsung kurang lebih selama 10 menit. Pada tahap ini pendidik mempersiapkan peserta didik untuk mengikuti kegiatan pembelajaran, meriview pelajaran yang lalu dengan mengajukan pertanyaan dan mengaitkan pengetahuan sebelumnya dengan materi yang akan dipelajari, memberikan motivasi kemudian menyampaikan tujuan pembelajaran.

b) Kegiatan inti
Pada pertemuan kedua ini, pendidik meminta peserta didik untuk duduk berkelompok sesuai dengan kelompok yang telah ditentukan pada pertemuan sebelumnya. Setelah peserta didik duduk dalam kelompok masingmasing, pendidik membagikan teks cerita kepada setiap kelompok dan melaksanakan pembelajaran dengan menerapkan langkah-langkah pembelajaran model Cooperative Integrated Reading and Composition. Pada saat kegiatan pelaksanaan siklus II pertemuan kedua sama dengan pelaksanaan pada siklus II pertemuan pertama. Kegiatan yang membedakan yaitu pendidik lebih mengawasi dan mengontrol peserta didik dalam belajar. Pendidik dan peneliti berusaha semaksimal mungkin agar peserta didik memahami materi pelajaran menulis ringkasan seperti menemukan gagasan utama, membuat ringkasan dengan ejaan dan tanda baca yang tepat.

c) Kegiatan penutup

Pada kegiatan ini, peserta didik dibimbing untuk menyimpulkan pembelajaran. Selanjutnya diberikan penjelasan bahwa materi pembelajaran ini telah selesai. Kemudian pelajaran ditutup dengan membaca hamdalah bersama peserta didik dan mengucapkan salam.

Pada Senin, 16 April 2018 pendidik mengadakan teks siklus 
II untuk mengetahui pemahaman peserta didik dalam menulis ringkasan materi "Mengenal Tari Pendet dari Bali".

\section{c. Observasi/Pengamatan}

Pengamatan terhadap tindakan menulis ringkasan isi cerita menggunakan model pembelajaran Cooperative Integrated Reading and Composition untuk memperoleh informasi tentang respon peserta didik dan pendidik dalam melaksanakan pembelajaran siklus II. Pengamatan dilakukan dengan objektif dan sistematis.

\section{d. Hasil Belajar siklus II}

Penilaian peserta didik meliputi penilaian proses pada saat pramenulis, menulis, merevisi, mengedit dan mempublikasikan. Penilaian menulis ringkasan menggunakan model pembelajaran Cooperative Integrated Reading and Composition dengan KKM yang telah ditetapkan sekolah yaitu 75 . Pendidik memberikan tes diskusi kelompok setiap pertemuan. Pertemuan satu pada siklus II terdapat tiga kelompok yang tuntas yaitu kelompok satu, tiga, dan empat dengan nilai $80,80,85$ sedangkan kelompok dua masih terdapat peserta didik yang kurang mengerti dalam menemukan gagasan utama. Sedangkan pada pertemuan II siklus II semua kelompok tuntas dengan nilai 80 , 80, 80, 85. Pada pertemuan III siklus II pendidik mengadakan tes siklus II terdapat 15 orang peserta didik yang tuntas dengan nilai tertinggi 90 dan 3 orang yang tidak tuntas.

\section{e. Refleksi}

Kegiatan refleksi dilakukan pada setiap tahapan pembelajaran dilakukan secara kolaboratif antara wali kelas V MIN 1 Pesisir Selatan dengan peneliti. Berdasarkan siklus II diketahui bahwa dalam pelaksanaan pembelajaran menulis ringkasan isi cerita melalui model pembelajaran

Cooperative Integrated Reading and Composition kelas V dan didukung dengan variasi teks cerita, penggunaan bahasa yang digunakan pendidik dalam menyampaikan materi sehingga mudah dipahami oleh peserta didik, kesungguhan peserta didik dalam mengerjakan tes serta bimbingan pendidik dan peneliti dalam pembelajaran karena pendidik dan peneliti ingin melihat pemahaman peserta didik dalam menulis ringkasan isi cerita.

Pada siklus II ini peserta didik terlihat sudah sangat baik dalam pembelajaran. Hal ini terbukti dari hasil belajar kelompok dan hasil belajar siklus II. Pada saat kegiatan pramenulis dan menulis, peneliti dan pendidik sudah sepenuhnya membangkitkan minat belajar peserta didik. Peserta didik terlihat serius dalam belajar. Setelah peserta didik mengerti dengan penjelasan pendidik mengenai 
menulis ringkasan. Peserta didik diberikan lembar kerja dengan teks cerita yang berbeda.

Pada saat bekerja dalam kelompok, peserta didik membaca bergantian dan tidak ada yang meribut serta tidak ada yang keluar masuk kelas. Pada tahap merevisi dan mengedit kembali hasil diskusi dengan memperhatikan ejaan, tanda baca, gagasan utama setiap paragraf serta mengurutkan gagasan utama kemudian menuliskan kembali dalam bentuk ringkasan. Selain itu peserta didik mampu menyelesaikan tes terkait teks yang diberikan seperti menentukan kata kunci setiap paragraf, pokok pikiran setiap paragraf serta menemukan informasi dari teks serta menulis ringkasan isi cerita.

Pada tahap pascamenulis yaitu mempublikasikan. Peserta didik membacakan hasil diskusi mereka ke depan kelas dengan intonasi yang tepat dan suara yang lantang sedangkan peserta didik lain memperhatikan dan memberi tanggapan kepada peserta didik yang tampil.

Pada siklus II ini peserta didik sudah dapat menulis ringkasan isi cerita. Pendidik juga telah maksimal dalam pembelajaran karena pendidik membimbing peserta didik secara kelompok sehingga secara tidak langsung telah tertanam rasa tanggung jawab untuk menyelesaikan tugas di jiwa peserta didik.

\section{KESIMPULAN}

Model pembelajaran Cooperative Integrated Reading and Composition dapat meningkatkan kemampuan menulis ringkasan isi cerita peserta didik. Peserta didik telah mampu menggunakan tanda baca serta ejaan yang tepat, menemukan gagasan utama setiap paragraf serta menyusun gagasan utama tersebut menjadi sebuah ringkasan. Hal ini dapat dibuktikan dari hasil tes yang meningkat setiap siklus. Pada siklus I terdapat 10 orang peserta didik yang tidak tuntas dan 8 orang yang tuntas dengan presentase ketuntasan 44,44\%. Sedangkan pada siklus II terdapat 3 orang peserta didik yang tidak tuntas dan 15 orang peserta didik yang tuntas dengan presentase ketuntasan 83,33\%. Jadi dapat disimpulkan bahwa model pembelajaran Cooperative Integrated Reading and Composition dapat meningkatkan kemampuan menulis ringkasan isi cerita peserta didik dengan menerapkan ejaan yang benar, menentukan tanda baca yang tepat, menemukan gagasan utama, mengurutkan gagasan pokok pikiran tiap paragraf.

\section{DAFTAR PUSTAKA}

Akbari, Ikhsan. (2013). Penerapan Model

Pembelajaran 
Kooperatif Tipe Cooperative

Integrated Reading And

Composition (CIRC) untuk

Meningkatkan Kemampuan

Meringkas Isi Buku Cerita

Siswa Kelas V SDN 02 Ngasem

Colomadu Karanganyar.

Bandung: Nusa Media.

Aqib, Zainal. (2009). Penelitian

Tindakan Kelas. Bandung: CV.

Yrama Widya.

Basit, Abdul. (2013). Jurnal Kependidikan Islam Tingkat Dasar, Vol. III'. Padang: Tarbiyah Al Awlad.

Faisal. (2014). Sukses Mengawal Kurikulum 2013 di SD. Yogyakarta: Diandra Creative.

Istarani dan Ridwan Muhammad. (2014). 50 Tipe Pembelajaran Kooperatif. Medan: CV Iscom Medan.

Romiana Magdalena. (2017).

Pendidikan Program Bahasa Inggris, 9 (2). 194.

Sharan, Shlomo. (2012). Handbook of Cooperative Learning. Yogyakarta: Familia.

Suprihatiningrum, Jamil. (2016). Strategi dalam Pembelajaran
Teori dan Aplikasi,

Yogyakarta: Ar-Ruzz Media.

Suprijono, Agus. (2013). Cooperative Learning teori dan Aplikasi PAIKEM, Yogyakarta: Pustaka Pelajar.

Susanti. (2014). Peningkatan Kemampuan Menulis Ringkasan Isi Cerita Melalui Model Pembelajaran Kooperatif Tipe Cooperative Integrated Reading And Composition (CIRC) Pada Peserta Didik Kelas V SDN 04 Olo Kecamatan Nanggalo. Padang: IAIN IB Padang.

Susanto, Ahmad. (2013). Teori Belajar dan Pembelajaran di Sekolah Dasar, Jakarta: Kencana.

Sudijono, Anas. (2014). Pengantar Statistik Pendidikan. Jakarta: PT Grafindo Persada.

Yudhistira, Dadang. (2013). Menulis Penelitian Tindakan Kelas yang APIK. Jakarta: PT Grasindo.

Zulfahmi HB. (2014). Kependidikan Islam Tingkat Dasar. 4 (1), 333. 